\title{
NOTE
}

\section{Hepatopancreatic brush border lysis (HBL) - a new bacterial disease of the shrimp Palaemon elegans}

\author{
Günter Vogt* \\ Department of Zoology 1, University of Heidelberg, Im Neuenheimer Feld 230, D-69120 Heidelberg, Germany
}

\begin{abstract}
Hepatopancreatic brush border lysis (HBL) is a new bacterial disease of Palaemon elegans found in 1 shrimp from a rock pool of the northern Adriatic Sea. The HBL bacteria are Gram-negative, elongate and slightly curved, and measure up to $7 \times 0.2 \mu \mathrm{m}$. They were observed only extracellularly in the lumina of hepatopancreatic tubules. The grade of infection varied considerably among the tubules. A typical cytopathological feature of HBL infection is the unusual end-toend contact of bacteria with individual microvilli which eventually induces rupture of the microvillous border. The bacteria in the lumen may live on the discharged contents of such lysed cells. Only R-cells and F-cells are contacted and lysed and not B-cells.
\end{abstract}

KEY WORDS: Palaemon elegans - Decapoda - Crustacea Hepatopancreas Bacterium Disease

Palaemon elegans is one of the most common shrimp of European coastal waters, particularly of the Mediterranean Sea and the Atlantic Ocean. Despite the abundance and wide geographical range of this species little is known about its diseases. In the last few years, I have described 2 new viruses, Palaemon B-cell reo-like virus (Vogt 1992a) and Bay of Piran shrimp virus (Vogt 1996), and a rickettsial infection (Vogt 1992b) from specimens sampled from the Bay of Piran, Adriatic Sea. This paper reports on a further disease of Palaemon elegans from the same location, a bacterial infection with an unusual cytopathology.

Materials and methods. Seven mature females of Palaemon elegans Rathke, 1837 (Crustacea, Decapoda, Palaemonidae) were collected from a rock pool on the Savudrija peninsula (Istria, Croatia), and fixed for histological examination. For light microscopy, samples of the hepatopancreas, stomach, anterior part of the midgut, ovary, musculature and connective tissue were fixed in Bouin's solution and embedded in paraf-

•E-mail:vogt@sirius.mgen.uni-heidelberg.de fin. The sections were stained with $H \& E$. Samples for electron microscopy were fixed in cold $3.5 \%$ glutaraldehyde diluted in Sörensen's buffer at $\mathrm{pH} 7.4$ for $2 \mathrm{~h}$. Thereafter, they were rinsed in $0.1 \mathrm{M}$ Sörensen's buffer, postfixed in $1 \%$ osmium ferrocyanide for $2 \mathrm{~h}$, successively washed in Sörensen's buffer and $0.05 \mathrm{M}$ maleate buffer at pH 5.2, stained en bloc with $1 \%$ uranyl acetate in maleate buffer for $2 \mathrm{~h}$, dehydrated through a graded series of ethanol, and embedded in Spurr's resin. Ultrathin sections were contrasted with lead citrate for $2 \mathrm{~min}$ and examined with a Zeiss EM 9-S2 electron microscope.

Results and discussion. Hepatopancreatic brush border lysis (HBL) bacteria were detected in 1 out of the 7 mature females investigated. Of the remaining 6 specimens 2 were healthy, 1 was infected with Palaemon B-cell reo-like virus (Vogt 1992a), 1 with Bay of Piran shrimp virus (Vogt 1996), 1 with rickettsiae (Vogt $1992 \mathrm{~b}$ ) and 1 with both PBRV and rickettsiae.

HBL bacteria were only found in the hepatopancreas, and not in the stomach, anterior part of midgut, ovary, musculature or connective tissue. Their distribution pattern in the several hundred tubules of the infected female was not uniform: some tubules were heavily infected, others not at all. The bacteria were exclusively located in the tubular lumen (Fig. 1a, b) particularly in the narrow indentations of the tubules (for microscopic anatomy of the hepatopancreas of Decapoda see Vogt 1994). The bacteria were easily visible in ultrathin sections and could also be recognized in semithin sections stained with Richardson's solution but not in Bouin's fixed and H\&E stained paraffin sections.

HBL bacteria are elongate and slightly curved and measure up to $7 \times 0.2 \mu \mathrm{m}$ in ultrathin sections (Fig. 1b, c). Their length is very variable but their width is fairly constant. They have cell walls like Gramnegative bacteria (Fig. 1d, e) and they contain many 


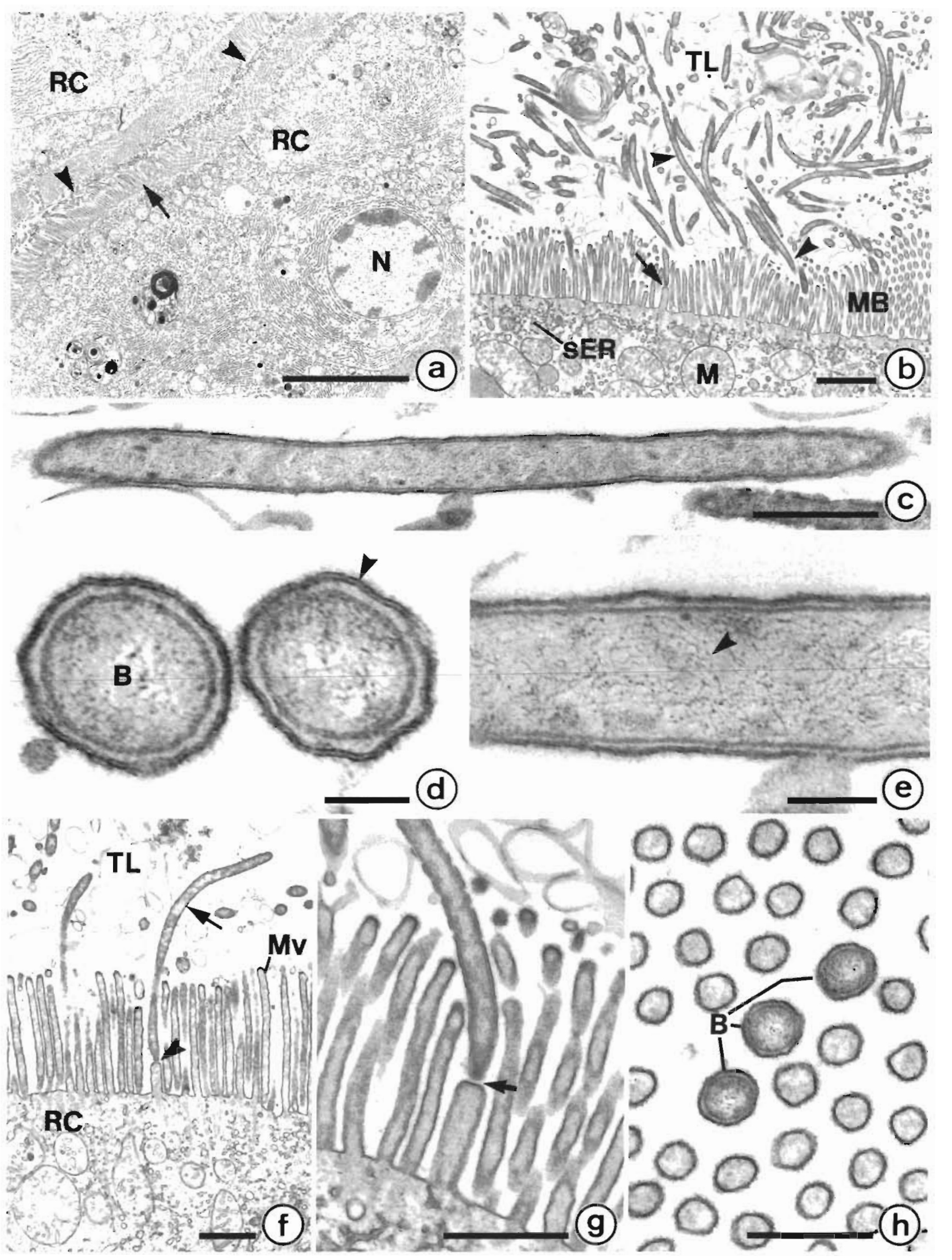


Fig. 1. Hepatopancreatic brush border lysis (HBL) bacteria in tubule lumen of the hepatopancreas of Palaemon elegans and in close contact with microvilli. (a) Bactena (arrowheads) in lumen between adjacent R-cells (RC) Arrow microvillous border $\mathrm{N}$ : cell nucleus. Scale bar $=1.0 \mu \mathrm{m}$. (b) Bactena (arrowheads) in tubule lumen (TL) and in contact with microvill (arıow) M mitochondrium; MB: microvillous border; sER smooth endoplasmic retıculum Scale bar $=2 \mu \mathrm{m}$. (c) Longitudinal section of bacterium Scale bar $=1 \mu \mathrm{m}$. (d) Cross section of 2 bacterna (B) Arlowhead outer membrane of cell wall Scale bar $=100 \mathrm{~nm}$. (e) Close-up of longitudinal section of bactcrium with fibrillar. DNA-like structures (arrowhead) Scale bar = $100 \mathrm{~nm}$ (f) Bacterlum (ar row) 'diving' into microvilluus border of R-cell and depressing individual nicrovillus (arrowhead) Mv normal miciovillus Scale bar = $1 \mu \mathrm{m} .(\mathrm{g})$ End-to-end contact (arrow) between bacterium and microvillus. Scale bar $=1 \mu \mathrm{m}$ (h) Cioss section of microvillous border with 3 bacteria in between. Scale bas $=500 \mathrm{~nm}$

fibrillar strands which are most probably DNA (Fig. 1e). The most characteristic teature of HBL infection is the unusual contact of individual bacteria with microvilli (Fig. 1f, g). The bacteria seem to 'dive' into the microvillous border (Fig. 1f, h) by depressing single contacted microvilli (Fig. $1 \mathrm{f}, \mathrm{g}$ ). They have always a close end-to-end contact with such depressed microvilli (Fig. 1g). Of the 3 mature cell types of the hepatopancreas only R-cells and F-cells are contacted and not $B$-cells. Eventually, contacted microvillous borders dis- integrate (Fig 2a) and the contents of the respective cells are discharged into the tubular lumen (Fig. 2b) Interestingly, the arganelles of such contacted cells are not transformed prior to lysis (Fig. 1b, f). The bacteria which multiply in the tubule lumen by binary fission (Fig. 2c) seem to live on the debris of lysed cells.

Usually, the hepatopancreatic tubule system of decapods is free of bacteria. The stomach-gut tract. in contrast, often contains saprophytic bacteria which have been internaluzed with the feed (Sugita et al.

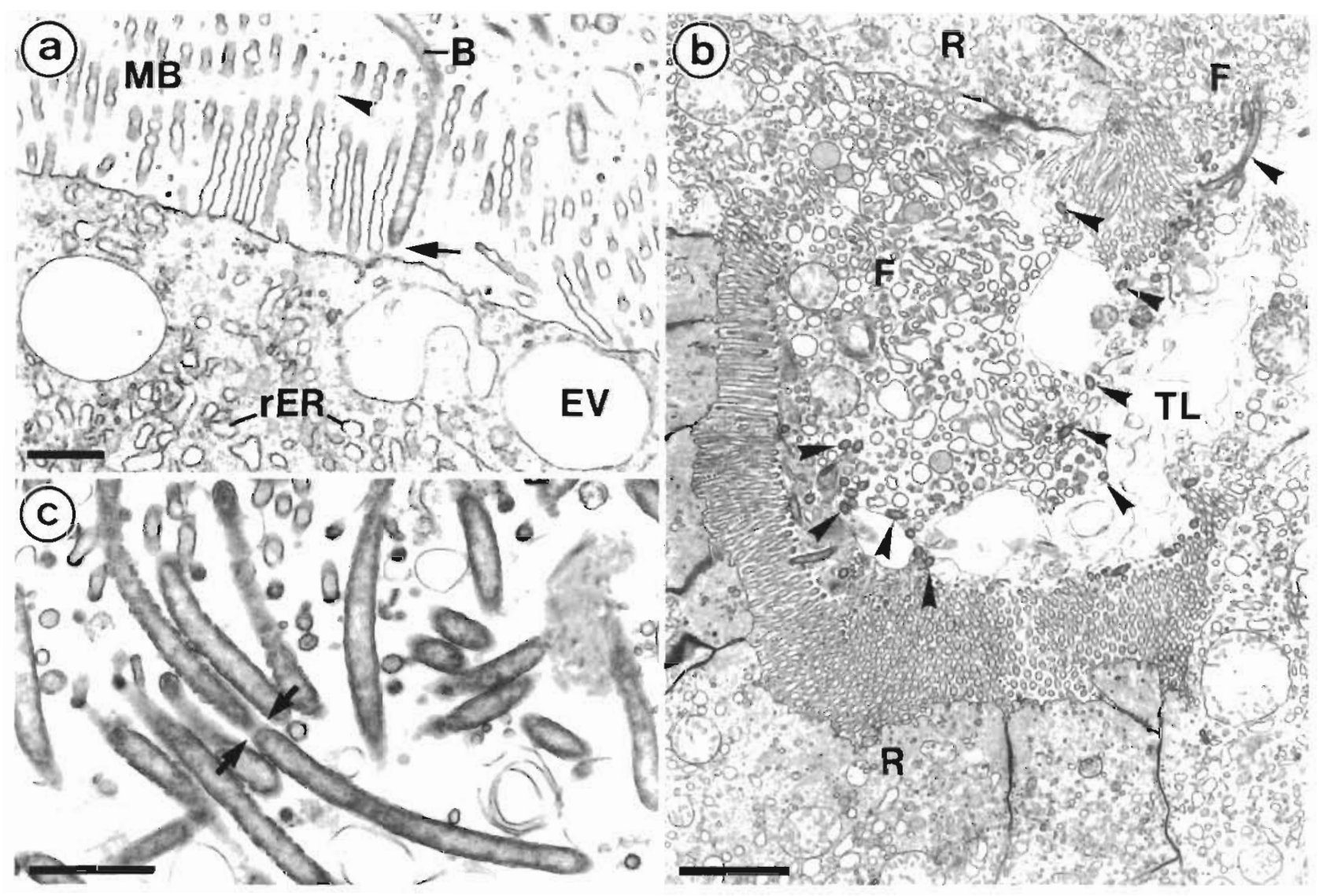

Fig. 2. Lysis of hepatopancreatocytes of Palaemon elegans by HBL bacterla (a) Degenerating microvillous border (MB) of bacteria (B) contacted (arrow) F-cell. Arrowhead: vesiculating microvillus EV digestıve enzyme-contannng vacuole; rER rough endoplasmic reticulum. Scale bar $=1 \mu \mathrm{m}$ (b) Lytıc F-cells (F) discharging their contents into the tubule lumen (TL) Arrowheads indicate bacteria arranged along ruptured cell apıces. $R \cdot R$-cell. Scale bar $=2 \mu \mathrm{m}$ (c) Binary fission (arrows) of bacterium in tubule lumen Scale bar $=1 \mu \mathrm{m}$ 
1987). Such opportunistic microorganisms can become pathogenic just by chance, under stress situations or if they enter 'wrong' body compartments (Johnson 1983, Brock \& Lightner 1990, Chen et al. 1992, Lightner 1993, Song et al. 1993, Pizzutto \& Hirst 1995). Since the HBL bacteria occurred only in the lumen of the hepatopancreatic tubules, they were probably acquired via the feed.

The most prominent feature of HBL cytopathology is the depression of individual, bacteria-contacted microvilli. Such a peculiar kind of bacterial attachment has not previously been reported for aquatic animals (Johnson 1983, Kinne 1983-1990). Adhesion of bacteria to surface structures of target cells is often a prerequisite of their pathogenicity (Huq et al. 1986, Yamamoto \& Yokota 1989). The degree of virulence even appears to be directly correlated with the intensity of attachment, as shown by Chen \& Hanna (1994) for Vibrio anguillarum and Vibrio parahaemolyticus in the prawn Penaeus monodon. Adhesion is performed by lectin-like adhesins or other proteins which bind to carbohydrates or proteins on the surface of the host cells (Ofek \& Doyle 1994). The destruction of the host cell is then induced by punctual secretion of exotoxins from the attached bacteria or direct toxic interaction with surface molecules of the target cell (McGee \& Robinson 1985).

In HBL, the destruction of the contacted cells can clearly be related to the bacteria for the following reasons: (1) The observed discharge of R-cells and F-cells in the hepatopancreatic tubules is not just a sign of normal cellular replacement since aged R-cells and F-cells are removed in the collecting ducts and the antechamber of the hepatopancreas, not in the tubules, and are replaced from the mitotic centres at the blindended tips of the tubules (Vogt 1994). (2) The observed discharge also does not reflect extrusion of $\mathrm{R}$-cells and F-cells damaged by premature aging, chemicals, viruses, etc., because in such cells the organelles would be considerably transformed prior to rupture of the microvillous border (Vogt 1990). In HBL, however, the bacteria-contacted microvillous borders disintegrated before there was any obvious lesion. of the cell organelles (Fig. 2a, b).

Pathogenic bacteria often cause unspecific damage to the hepatopancreas. For instance, granulomatous hepatopancreatitis bacteria of Astacus astacus induce simultaneous lysis of larger areas of the hepatopancreatic epithelium (Vogt \& Rug 1997). HBL bacteria, in contrast, contact and lyse only individual R-cells and F-cells, not B-cells. R-cells are the nutrient absorbing and storing cells of the decapod hepatopancreas (Vogt 1994), and F-cells synthesize digestive enzymes (Vogt et al. 1989). The function of B-cells has not yet been established (Vogt 1993). Specific attachment of bac- teria to a particular host cell type is also known for some human diseases. For instance, Neisseria gonorrhoeae interacts only with non-ciliated cells of the human fallopian tube mucosa and not with ciliated cells (McGee \& Robinson 1985).

Since HBL was detected in only 1 specimen sampled from the wild several questions are still open and need further investigation: the taxonomic identity of the HBL bacteria, their geographical distribution, the exact route of infection, the temporal course of pathogenesis, and the grade of pathogenicity in wild populations

Acknowledgements. The author thanks Mrs Gisela Adam for skillful reproduction of the micrographs.

\section{LITERATURE CITED}

Brock JA, Lightner DV (1990) Diseases of Crustacea. Diseases caused by microorganisms. In: Kinne $O$ (ed) Diseases of marine animals, Vol III. Biologische Anstalt Helgoland, Hamburg, p 245-349

Chen D, Hanna PJ (1994) Immunodetection of specific Vibrio bacteria attaching to tissues of the giant tiger prawn Penaeus monodon. Dis Aquat Org 20:159-162

Chen SN, Huang SL, Kou GH (1992) Studies on the epizootiology and pathogenicity of bacterial infections in cultured giant tiger prawns, Penaeus monodon, in Taiwan. In: Fulks W, Main KL (eds) Diseases of cultured penaeid shrimp in Asia and the United States. Oceanic Institute, Honolulu, p 195-205

Huq A, Huq SA, Grimes DJ, O'Brien M, Chu KH, McDowell Capuzzo J, Colwell RR (1986) Colonization of the gut of the blue crab (Callinectes sapidus) by Vibrio cholerae. Appl Environ Microbiol 52:586-588

Johnson PT (1983) Diseases caused by viruses, rickettsiae, bacteria, and fungi. In: Provenzano AJ (ed) Pathobiology. The biology of Crustacea, Vol 6. Academic Press, New York, p 1-78

Kinne O (ed) (1983-1990) Diseases of marine animals, Vols 1-4. Biologische Anstalt Helgoland, Hamburg

Lightner DV (1993) Diseases of cultured penaeid shrimp. In MCVey JP (ed) CRC handbook of mariculture: crustacean aquaculture, 2nd edn, Vol 1. CRC Press, Boca Raton, p 393-496

McGee ZA, Robinson EN (1985) Molecular mechanisms by which pathogenic bacteria interact with host mucosal cells. In: Jackson GG, Thomas H (eds) The pathogenesis of bacterial infections. Bayer-Symposium VIII. SpringerVerlag, Berlin, p 8-16

Ofek I, Doyle RJ (eds) (1994) Bacterial adhesion to cells and tissues. Chapman \& Hall, New York

Pizzutto M, Hirst RG (1995) Classification of isolates of Vibrio harveyi virulent to Penaeus monodon larvae by protein profile analysis and M13 DNA fingerprinting. Dis Aquat Org 21:61-68

Song YL, Cheng W, Wang CH (1993) Isolation and characterization of Vibrio damsela infectious for cultured shrimp in Taiwan. J Invertebr Pathol 61:24-31

Sugita H, Ueda R, Berger LR, Deguchi Y (1987) Microflora in the gut of Japanese coastal crustacea. Nippon Suisan Gakkaishi 53:1647-1655

Vogt G (1990) Pathology of midgut gland cells of Penaeus monodon postlarvae after Leucaena leucocephala feeding. Dis Aquat Org 9:45-61 
Vogt G (1992a) Palaemon B-cell reo-like virus: a new virus from the hepatopancreas of the shrimp Palaemon elegans. J Invertebr Pathol 59:218-220

Vogt G (1992b) Enclosure of bacteria by the rough endoplasmic reticulum of shrimp hepatopancreas cells. Protoplasma 171:89-96

Vogt G (1993) Differentiation of B-cells in the hepatopancreas of the prawn Pendeus monodon. Acta Zool 74: $51-60$

Vogt $G$ (1994) Lufe-cycle and functional cytology of the hepatopancreatic cells of Astacus astacus (Crustacea, Decapoda). Zoomorphology 114:83-101

Responsible Subject Editor: J. E. Stewart, Dartmouth, Nova Scotia, Canada
Vogt $G$ (1996) Cytopathology of Bay of Piran shrmp virus (BPSV), a new crustacean virus from the Mediterranean Sea. J Invertebr Pathol 68:239-245

Vogt G, Rug M (1997) Granulomatous hepatopancreatitis: immune response of the crayfish Astacus astacus to a bacterial infection. Freshwater Crayfish 11 (in press)

Vogt G, Stocker W, Storch V, Zwilling R (1989) Biosynthesis of Astacus protease, a digestive enzyme from crayfish. Histochemistry 91:373-381

Yamamoto T, Yokota T (1989). Adherence targets of Vibrio parahaemolyticus in human small intestines. Infect Immun $57: 2410-2419$

Manuscript first received: December 2, 1996 Revised version accepted: March 18, 1997 